\title{
DE
}

DE GRUYTER

OPEN

Arch. Min. Sci. 62 (2017), 1, 177-188

Electronic version (in color) of this paper is available: http://mining.archives.pl

DOI 10.1515/amsc-2017-0013

JÓZEF MARKOWICZ*, SYLWESTER RAJWA**, STANISŁAW SZWEDA*

\section{MODELLING OF POWERED ROOF SUPPORT COOPERATION WITH THE FLOOR OF LOW BEARING CAPACITY IN THE ASPECT OF SHAPING THE SECTION DESIGN}

\author{
MODELOWANIE WSPÓŁPRACY OBUDOWY ZMECHANIZOWANEJ ZE SPĄGIEM O MALEJ \\ NOŚNOŚCI W ASPEKCIE KSZTALTOWANIA POSTACI KONSTRUKCYJNEJ SEKCJI
}

\begin{abstract}
The problem of cooperation of powered roof support with the floor in the aspect of shaping its design is presented. From the analysis of the simplifying assumptions considered so far in the methods for determination of roof support's base pressure on the floor, it results that they are not satisfied in the case of bases of the catamaran type, commonly used in currently manufactured roof supports. Model of cooperation of the base lying on the floor, prepared by the finite elements method is described and the results of computer simulation of the base action on the floor are given. Considering the results of numerical analyses, the factors influencing the pressure distribution of the base on the floor as well as its maximal value, have been identified.
\end{abstract}

Keywords: Powered roof support, pressure on the floor, modeling

W artykule przedstawiono zagadnienie współpracy sekcji obudowy zmechanizowanej ze spagiem o małej nośności w aspekcie kształtowania jej postaci konstrukcyjnej. Dotychczas stosowane metody analitycznego, bądź doświadczalnego wyznaczania nacisku spagnicy na spąg były adekwatne do postaci konstrukcyjnej sekcji obudowy zmechanizowanej charakteryzującej się spąnicami dzielonymi. Omówiono założenia upraszczające przyjmowane w metodzie Jacksona, traktujące zespół spągnic sekcji jako ciało idealnie sztywne spoczywające na sprężystym podłożu. Opisano również przykłady modelowania współpracy spagnicy sekcji obudowy zmechanizowanej ze spagiem, w których problem interakcji spągnicy i spągu potraktowano jako zadanie płaskie, przyjmując liniowo sprężystą charakterystykę spagu. Na Rys. 1 i 2 przedstawiono odkształcone modele spąnicy spoczywającej na węglowym spągu oraz rozkład nacisku spagnicy na spąg. Modele spagnicy, zbudowane metodą elementów skończonych, złożone były z elementów powłokowych o zmiennej grubości. Jakkolwiek stosowanie płaskich modeli interakcji spągnicy i spągu umożliwiło analizę rozkładu nacisku spągnicy na spąg, to modele te nie są adekwatne w przypadku spagnic typu katamaran, gdyż nie można przyjąć założenia niezależnego schematu obciążenia każdej ze spąnic.

* SILESIAN UNIVERSITY OF TECHNOLOGY, FACULTY OF MINING AND GEOLOGY, INSTITUTE OF MINING MECHANISATION, UL. AKADEMICKA 2, 44-100 GLIWICE, POLAND

** CENTRAL MINING INSTITUTE, PLAC GWARKOW 1, 40-166 KATOWICE, POLAND 
Wyniki pomiarów, wykonanych w wyrobisku ścianowym, jak również na stanowisku badawczym uzasadniają konieczność modelowania współpracy spagnicy ze spagiem z wykorzystaniem modeli przestrzennych. Model geometryczny spagnicy sekcji obudowy zmechanizowanej typu BW 16/34 POz i spagu, z podziałem na elementy skończone przedstawiono na Rys. 3. Model spagnicy wiernie odwzorowuje jej postać geometryczną, łącznie z nakładkami wzmacniającymi najbardziej wytężone obszary spagnicy. Przyjęto sprężysto-plastyczną charakterystykę spagu z liniowym umocnieniem (Rys. 4). Przykładowe obciążenie zewnętrzne spagnicy (Tabela 1) przedstawiono na Rys. 5. Wykresy zamieszczone na Rys. 6-10 świadczą o istotnie różnych rozkładach nacisku lewej i prawej części spagnicy na spąg.

Przeprowadzone symulacje komputerowe umożliwiły zidentyfikowanie czynników istotnie wpływających na współpracę spagnicy ze spagiem. Spośród czynników zależnych od projektanta sekcji na uwagę zasługuje jej postać konstrukcyjna. Projektując sekcję należy dążyć do uzyskania równomiernego rozkładu nacisku na powierzchni spagnicy, co jest równoznaczne z wymuszeniem zwrotu składowej poziomej obciążenia sekcji w stronę zawału. Zwrot tej siły, zależny między innymi, od względnych przemieszczeń stropnicy i stropu można kształtować poprzez odpowiednie zaprojektowanie toru ruchu stropnicy.

W podsumowaniu stwierdzono, że postać konstrukcyjna sekcji powinna podczas konwergencji stropu, wymuszać zwrot siły tarcia w stronę zawału. Ponadto podporność wstępną i roboczą sekcji należy ustalić na możliwie najniższym poziomie, zapewniającym jednakże poprawną współpracę sekcji ze stropem wyrobiska. Należy również dążyć do zaprojektowania spąnicy o możliwie największej powierzchni kontaktu ze spagiem poprzez jej maksymalne wydłużenie w kierunku czoła ściany. W przypadku słabych spagów należy rozważyć możliwość zastosowania sekcji dwuszeregowych z lemniskatowym prowadzeniem stropnicy zamiast sekcji jednoszeregowych z uwagi na korzystniejszy rozkład nacisku na spąg w tych sekcjach.

Słowa kluczowe: sekcja obudowy zmechanizowanej, nacisk na spag, modelowanie, pomiary

\section{Introduction}

The problem of pressure distribution of the base on the floor is especially important in the case of longwall panels with floor rocks of low bearing capacity. From 2D static models of power roof supports, it is known that the design parameters have impact on the value and position of resultant pressure and on its maximal amount. Pressure distribution, determined in such a way, should be taken into consideration in the analysis of correctness of matching the roof support to the given mining and geological conditions by comparison of maximal pressure on the floor rocks with the permissible value.

Due to use of powered roof support design with practically independent base movement (roof supports with divided bases) until the end of 1990-ties, analytical solutions as well as experimentally designed solutions were limited to 2D base models. Most frequently, the base was treated as a rigid body as the base rigidity is much higher than floor rigidity. To consider the changes in base rigidity requires using the numerical methods in solving the problem.

Use of the catamaran type of bases (i.e. connected with the rigid bridge) in the recently manufactured powered roof supports, makes that design of the support is now more important as regards an impact both on maximal pressure of the floor on the base and on pressure distribution on the floor-base contact surface. Such problems cannot be solved using only 2D models of floor and base.

In addition to the review of currently used methods for determination of floor pressure, the results of calculations with use of 3D FEM models of the floor and the base are presented below. Analysis of spatial FEM models has also enabled formulating the conclusions on the selection of design features of powered roof supports regarding its cooperation with the floor. 


\section{2D models of interactions between base and floor}

In the Polish mining industry, the Jackson method is frequently used to determine distribution of powered roof supports pressure on the floor. The essence of this method consists in looking into the balance of the powered roof support, treated as the rigid body, and in determination of intersection point of the resultant pressing force line of the roof on the roof support with the floor plane. In this method, the simplifications in a form of 2D static models of the roof support as well as by neglecting both gob pressure on a gob shield and friction force between roof and canopy, are used. It has been also assumed that the base (or two-base system) is a perfectly rigid body resting upon the perfectly elastic floor. These assumptions are equivalent to acceptance of linear distribution of base pressure on the floor. Therefore, depending on a position of the line of resultant load to the roof support, we have triangular, trapezoidal or even distribution of base pressure on the floor. In addition, modifications of Jackson method, consisting in including the gob pressure on the gob shield and friction force between roof and canopy in a static analysis of the roof support, are used (Płonka, 2009; Bukowiecki, 2010; Ptak, 2010; Szweda, 1987; Jaszczuk et al., 2008).

In (Gricajuk, 1979; Markowicz, 1997) the examples of modelling the cooperation of powered roof support's base with the floor, where deformability both the base and the floor are discussed, were described. There are the following joint features of the abovementioned models:

- treating the problem of base interaction with the floor as 2D problem,

- accepting the linearly elastic floor characteristics.

In the finite elements method the mine workings' floor is modelled by the elements of $2 \mathrm{D}$ deformations, but the base is treated as the 2D disk of constant thickness, or - considering the change in bending rigidity along the base - it is modelled by shell elements of changeable thickness.

However, by accepting the above simplifications using the presented above mathematical models of floor-base cooperation, it is possible to simulate the complex phenomena observed during a real operation.

In Fig. 1 and 2 the examples of deformed models of the base, built of shell elements of changeable thickness, resting on the coal floor as well as distribution of pressure exerted by base on the floor, in the case of two different heights of roof support operation, are presented. In both cases, friction force between powered roof support's base and the roof, of a direction towards longwall face, was assumed. Such a sense of friction force can be found, when during the roof support setting to load, the canopy moves back from the longwall face.

Simulation of the phenomenon of detachment of rear part of the base from floor, occurring during mining process, mainly in the case of rocks having high carrying capacity, requires acceptance of unilateral constraints at the contact of canopy with the floor or requires solving the problem by the method of successive approximations, which differ in the length of the section on which the nodes are separated at the contact between base and floor.

While the use of 2D models of interaction between the base and the floor enabled analyzing the distribution of base pressure on the floor, the models are not satisfied in the case of bases of the catamaran type. Connection of the bases with a rigid bridge and the system of rear links makes that we cannot assume separate load to each base. That requires examination of 3D model of the base and floor. 

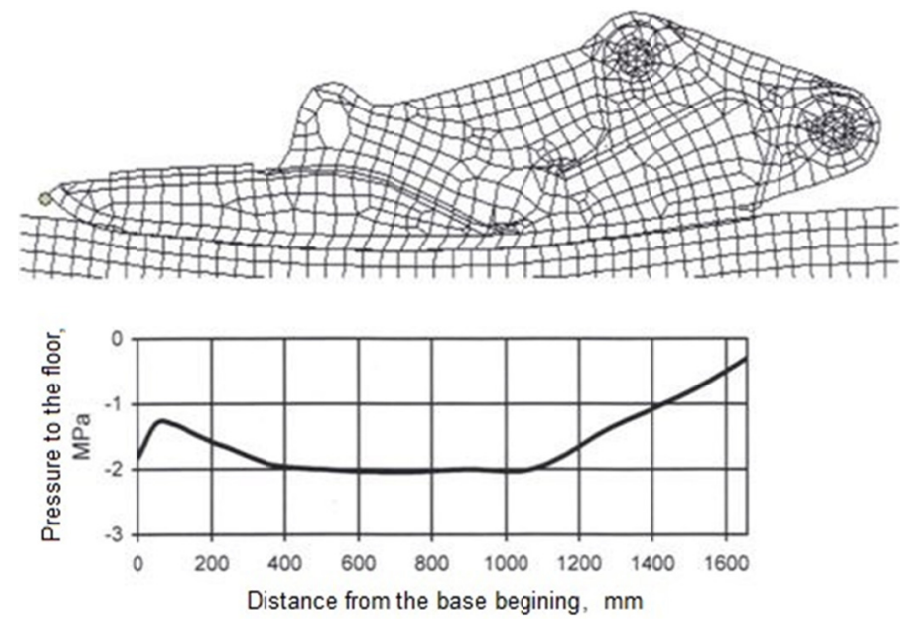

Fig. 1. Deformed model of the base and floor as well as determined distribution of pressure on the floor at roof support operational height $2.0 \mathrm{~m}$ (Markowicz, 2000)

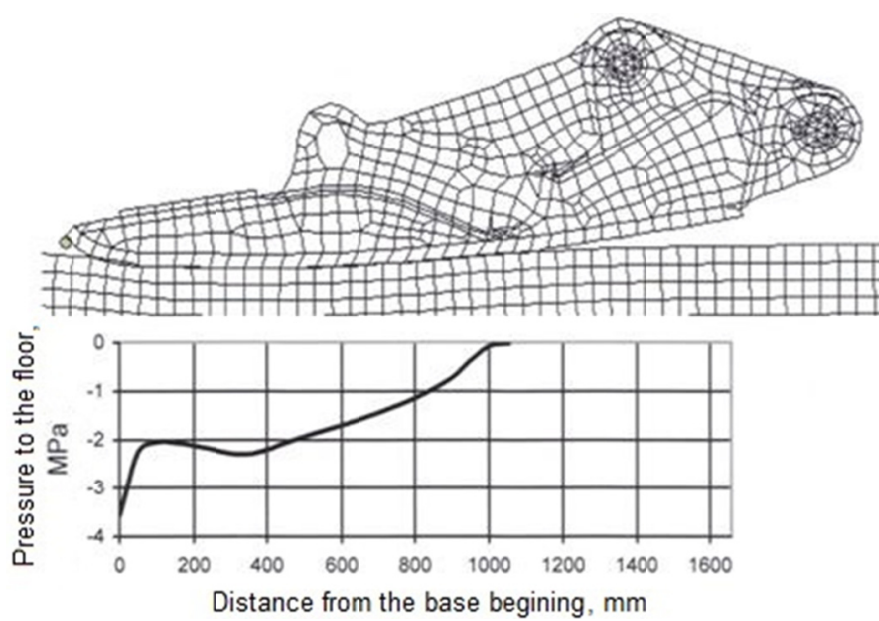

Fig. 2. Deformed model of the base and floor as well as determined distribution of pressure on the floor at roof support operational height $1.2 \mathrm{~m}$ (Markowicz, 2000)

\section{3D model of cooperation between base and floor}

\subsection{Model characteristics. Boundary conditions}

One-row powered roof support with a catamaran type of the base, resting on the elastic-andplastic floor, is the subject of examination. Model of the base has the geometric form of the base of BW 16/34 POz powered roof support. Model of the base and floor with the finite elements meshing is given in Fig. 3. During generation of finite elements meshing, the procedures improv- 
ing its quality, in the areas of planned contact, were used. Model of the base accurately recreates its geometric form together with overlays reinforcing the most strenuous areas of the base. Metal sheets are joined by fixed contact what has eliminated the necessity of detailed modelling of welded joints. Such simplification can be accepted in the case of modelling the contact of base with floor, as it slightly affects the result of calculations (Markowicz, 2010).

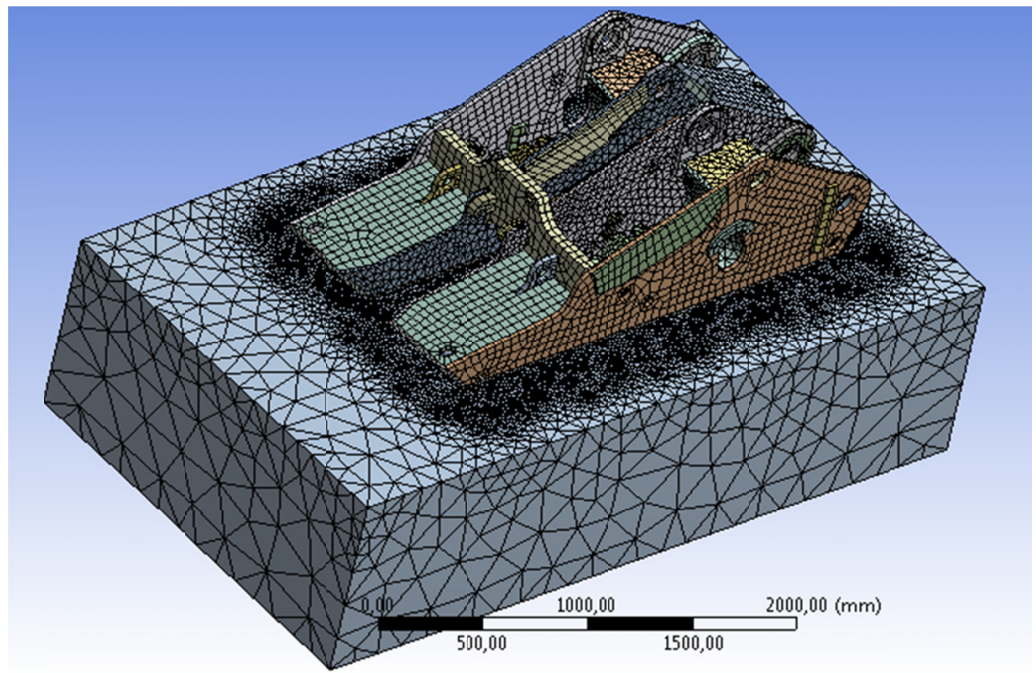

Fig. 3. Geometric model with partition into the finite elements

It was assumed that the roof support is resting on the floor, modelled by the elastic-andplastic material with a linear reinforcement. The examples of characteristics of floor material are given in Fig. 4. In the case of the discussed material, transition into plastic state occurs after exceeding the strain $5 \mathrm{MPa}$.

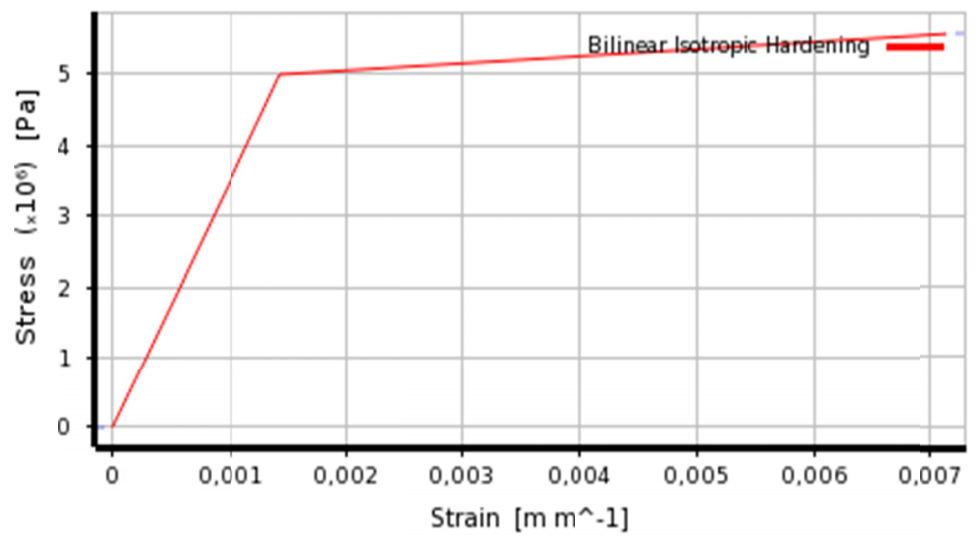

Fig. 4. Characteristics of floor material 
For the purpose of analysis of cooperation between base and floor, the contact elements of frictional type (Laczek, 2011) with the following parameters:

- friction coefficient $\mu=0.3$,

- symmetric contact,

- coefficient of rigidity - controlled by the programme with continuous update of rigidity,

- calculation method - Pure penalty

were defined.

When defining the contact, it was assumed that floor is a passive element and the bottom left and right sheets of the base are the active elements.

In relation to one-row powered roof support with lemniscate canopy guiding system, the base loading system includes forces in hydraulic cylinders and lemniscate links. It is also indispensable to determine directions of action of these forces - basing on analysis of kinematics of powered roof support. Example model of the base load is given in Fig. 5.

The following boundary conditions were entered in the case of a floor model:

- bottom plane of the model was fixed by depriving of all degrees of freedom,

- in the side planes there was no possibility to move in a direction perpendicular to those planes.

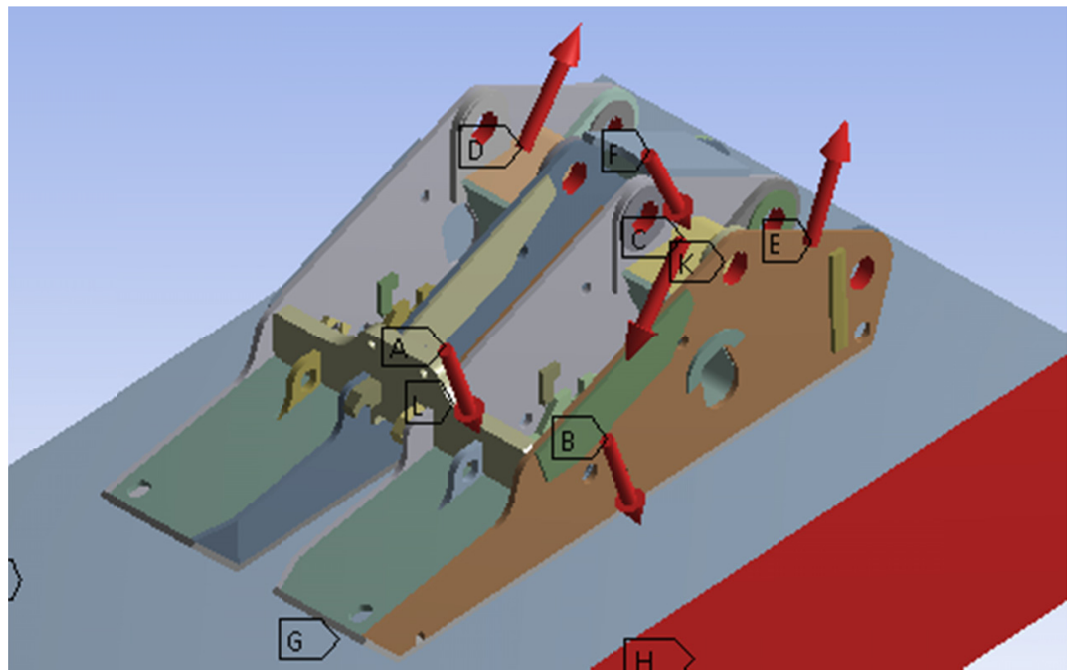

Fig. 5. Model of loading the base

\subsection{Example of the analysis of interaction between base and floor}

Floor parameters as well as forces in legs and roof support links are data indispensable for computer simulation of cooperation between the floor and base apart from the base geometric and material features. Values of these forces can be calculated in the result of 3D analysis of static model of the roof support or they can be determined experimentally by the measurements taken in 
the testing facility or directly in a longwall panel, e.g. (Markowicz, 1985; Geosoft, 2013). Determination of these forces in underground conditions requires special measuring instrumentation.

In table 1, the forces in legs and links for one of the variants of loading the roof support are specified. Senses of the vectors of each force conform to those presented in Fig. 5. Examples of calculations, selected results of which are given below, which were made assuming a cooperation of the base with the floor of low load-bearing capacity - it was assumed that plasticity of rocks making the floor starts at reduced strain equal to $0.1 \mathrm{MPa}$.

TABLE 1

Examples of forces in legs and links

\begin{tabular}{|c|c|c|c|c|c|}
\hline \hline \multicolumn{2}{|c|}{ Force in the leg, [kN] } & \multicolumn{4}{|c|}{ Force in the link, [kN] } \\
\hline Left & Right & Front left & Front right & Rear left & Rear right \\
\hline 2081.8 & 2402.1 & 266.2 & 724.1 & 36.2 & 293.1 \\
\hline
\end{tabular}

In Fig. 6 distributions of displacements in the floor occurring in two planes perpendicular to the longwall face and passing through the roof support's legs axes - right one (Fig. 6a and 6b) and left one (Fig. 6c and 6d), are presented. Bottom sheet, both of right and left part of the base contacts with the floor by its entire surface. Due to load asymmetry, under right part of the base (Fig. 6a and 6b) there are significantly greater dislocations in the floor comparing to the floor area under the left part of the base (Fig. 6c and 6d).

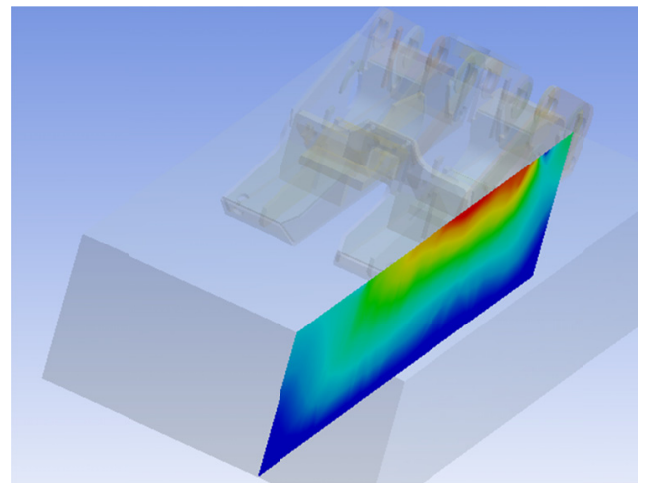

a - right part of the base

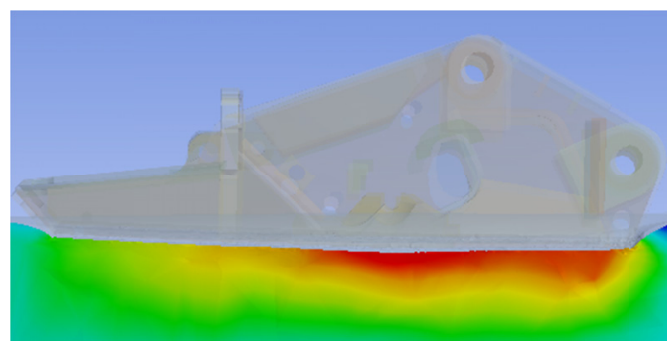

$\mathrm{b}$ - right part of the base
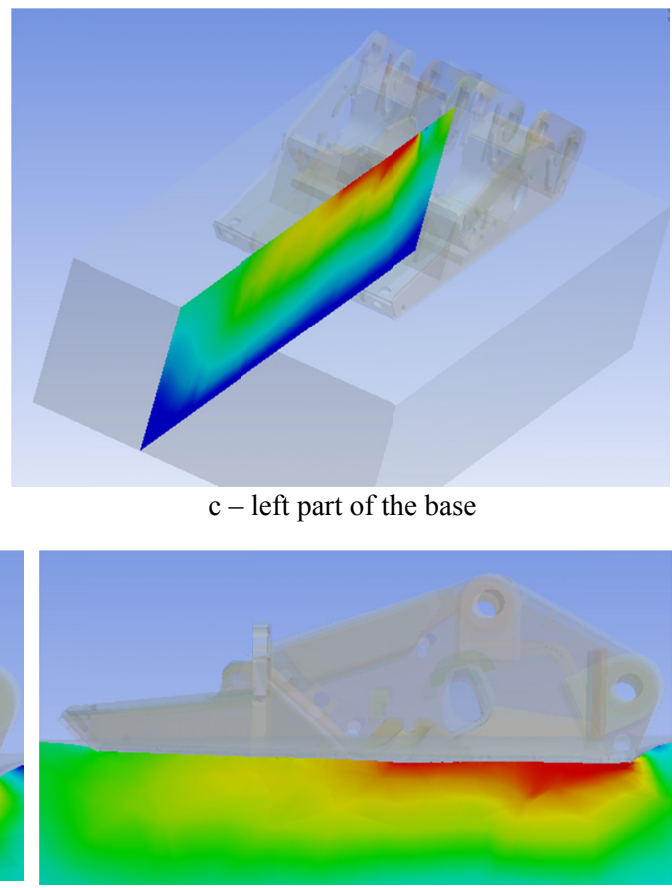

$\mathrm{d}$ - left part of the base

Fig. 6. Distribution of displacements of the floor 
In the case of analyzed asymmetry of load to the roof support, where the right part of the base conveys a greater load comparing to the left part of the base, distribution of pressure to the floor differs significantly as well, see Fig. 7. Both the maximal pressure and intensity of its change in left part of the base - solid line - and in its right part - broken line - differ significantly.

Significant difference in interaction of left and right part of the base can also be seen in the vertical plane passing through the legs' pockets (Fig. 8).

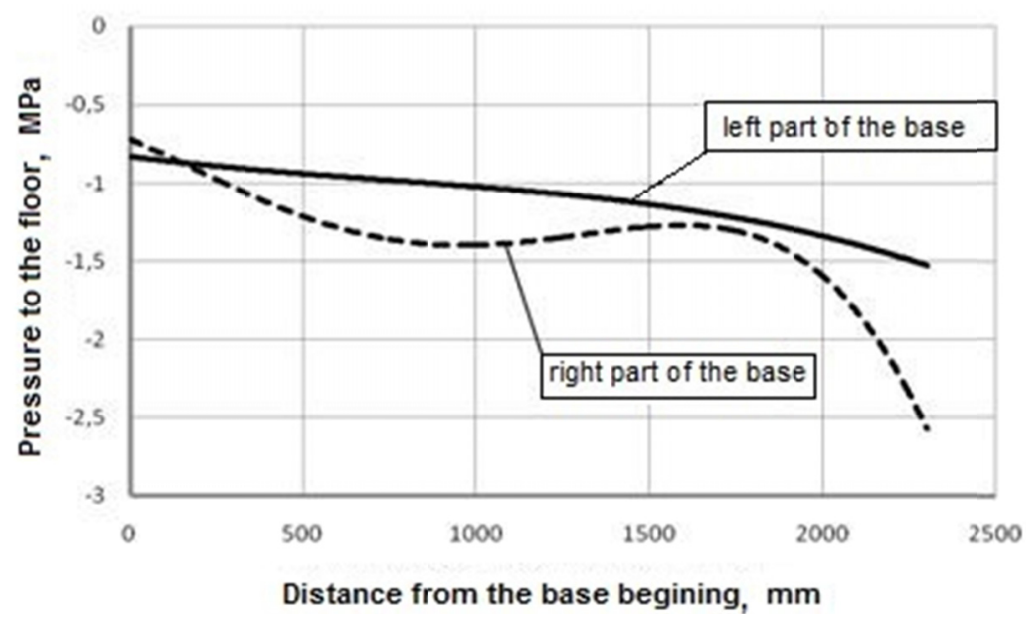

Fig. 7. Comparison of pressure distribution for left and right part of the base

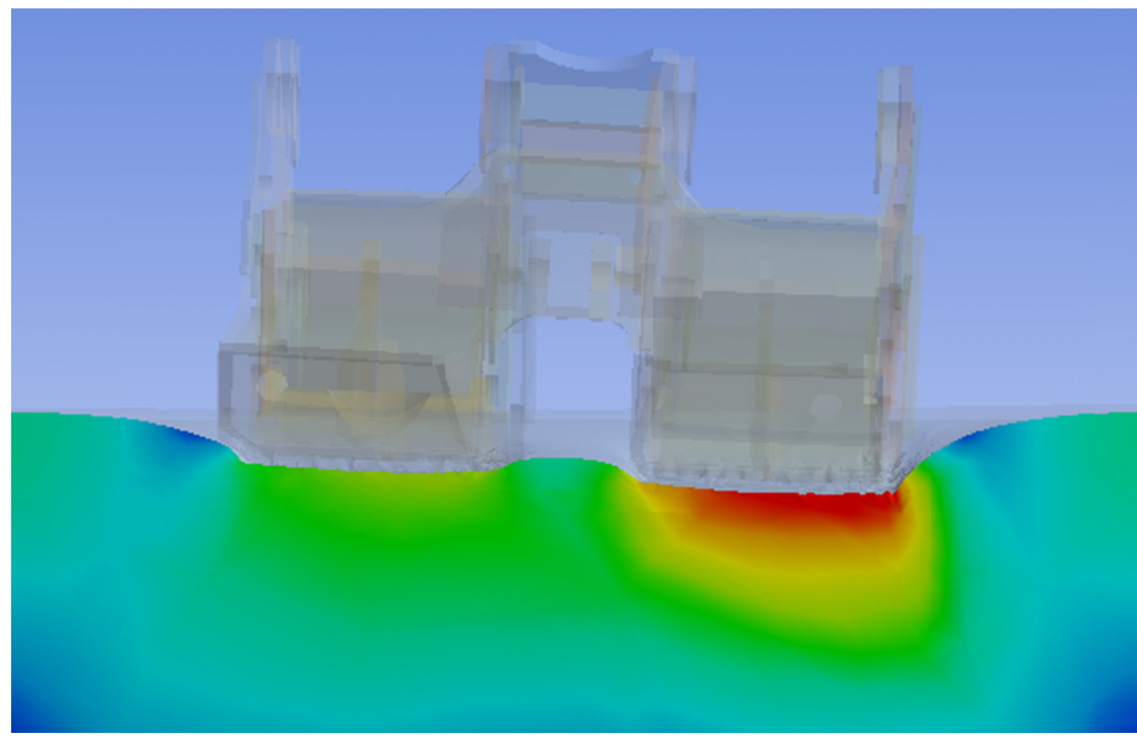

Fig. 8. Displacements of floor in the vertical plane passing through the legs' pockets 
The above mentioned calculation results concern the loading variant occurring in a condition roof convergence i.e. in the case, when the horizontal component of roof support resultant load has a sense towards the gob. In such case of external load to the roof support, the base has full contact with the floor through the surface of bottom sheet.

3D models of base and floor cooperation also enable analyses of the cases of detachment of part of the base from the floor. As an example, in Fig. 9 a deformed floor of the same characteristic as in the previous example, when the vertical external load is applied along the roof support's symmetry plane, is presented. In this case, contact between base and floor cover about $60 \%$ of metal sheet surface. Distribution of pressure along the base in this load variant is given in Fig. 10 .

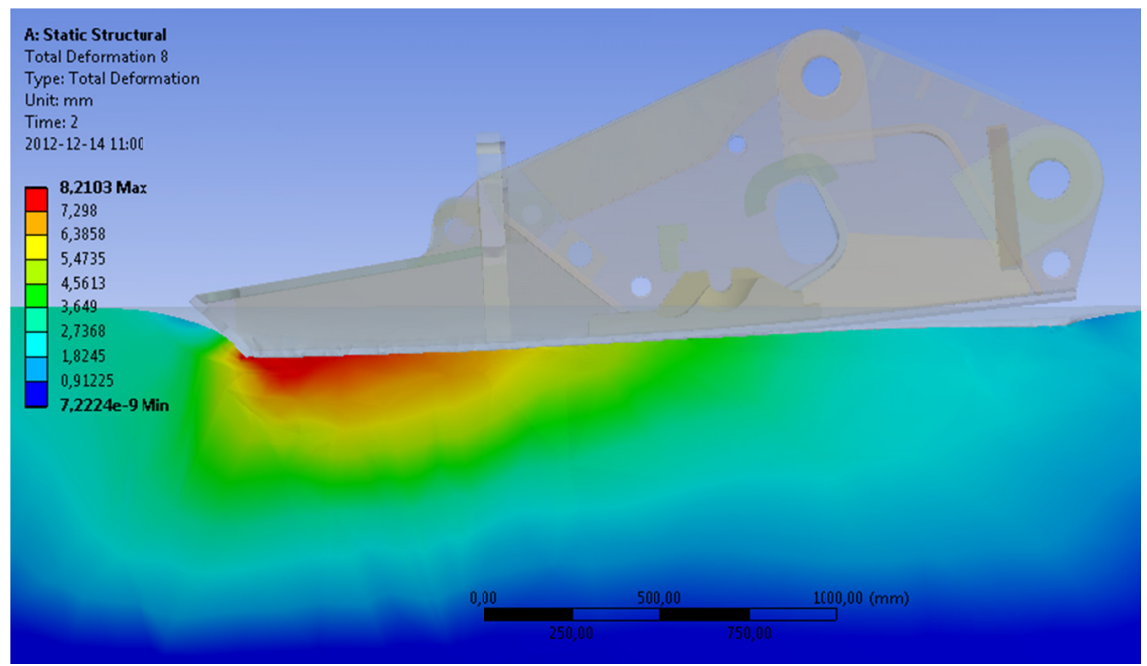

Fig. 9. Displacements of base and floor

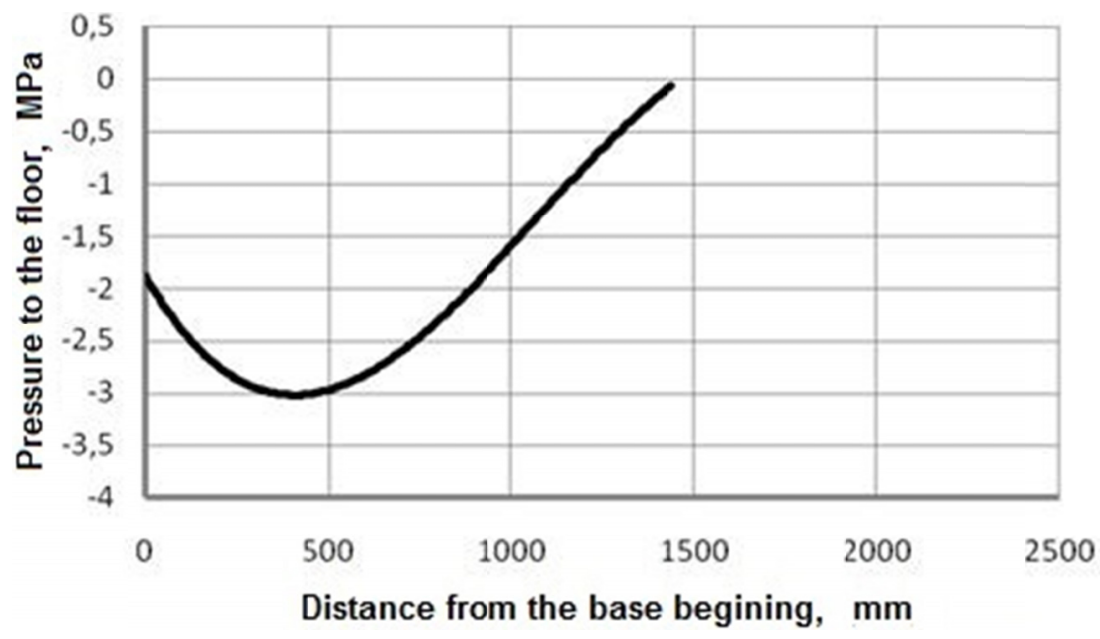

Fig. 10. Distribution of pressure 
Detachment of rear part of the base results in a significant increase of pressure to the floor in a front part of the base. In this case, maximal amount of pressure to the floor is few times higher than in the case, when the base contacts with floor on its entire bottom surface.

\section{Designing of powered roof in the aspect of its cooperation with soft floor}

Cooperation of roof support's base with the floor and the resulting distribution of base pressure depend on many factors. Most important of them are as follows:

- external load to the roof support (its value, direction and sense),

- type of floor rocks,

- type of roof support design and its load-bearing capacity,

- height of roof support operation

The factors dependent on mining-and-geological conditions, such as type of floor rocks and their properties, height of roof support operation, which depends on thickness of the mined seam, are of crucial importance. Other factors depend on designer of the powered roof support, as its final design is important.

In the case of powered roof support designed for operation in a condition of soft floor rocks, the possibly of most even pressure on the floor should be ensured. From the analysis of calculated distribution of base pressure on the floor, it results that for the presented model of powered roof support with canopy's lemniscate operation system and the most frequent load from the rock mass, the maximal pressure can be noticed in a front part of the base. Distribution of pressure on the floor depends, to a high degree, on the external load acting on the roof support from the rock mass side, especially on load amount and on the sense of its horizontal component.

Sense of the horizontal component of the roof support's resultant load depends on relative movement at the contact surface of the canopy with the roadway roof rocks as well as on the gob shield load and its movement in relation to gob rocks. Movement of the roof support's canopy, relative to the roadway roof, can be planned to some extend by a proper designing of the canopy movement trajectory - by designing the proper shape of lemniscate curve. Example of lemniscate curve is given in Fig. 11. If during roof convergence, the canopy movement towards longwall face is forced (range of heights from $\mathrm{H}_{1}$ to $\mathrm{H}_{2}$ and from $\mathrm{H}_{3}$ to $\mathrm{H}_{4}$ in Fig. 11), such a canopy movement causes that horizontal component of the resultant load has a sense towards gob. For the range of roof support heights from $\mathrm{H}_{2}$ to $\mathrm{H}_{3}$ during roof convergence, the canopy moves towards gob, what causes that friction force has a sense towards the longwall face.

Sense of horizontal component of the resultant roof support load towards the gob causes loading down of rear part of the base, in consequence it moves the area of maximal pressure towards the middle section of the base. Sense of horizontal component of the resultant roof support load towards the longwall face causes very disadvantageous pressure distribution. Maximal pressure can be found in the front part of the base. In the consequence, the front part of the base is sinking in the floor and its rear part detaches from floor surface.

Trajectory of the canopy movement can be planned already at the powered roof support designing stage by changing dimensions of four-bar linkage, sides of which determine centres of joints of lemniscate links fixation in the base and in the gob shield (Bukowiecki et al. 2012). 


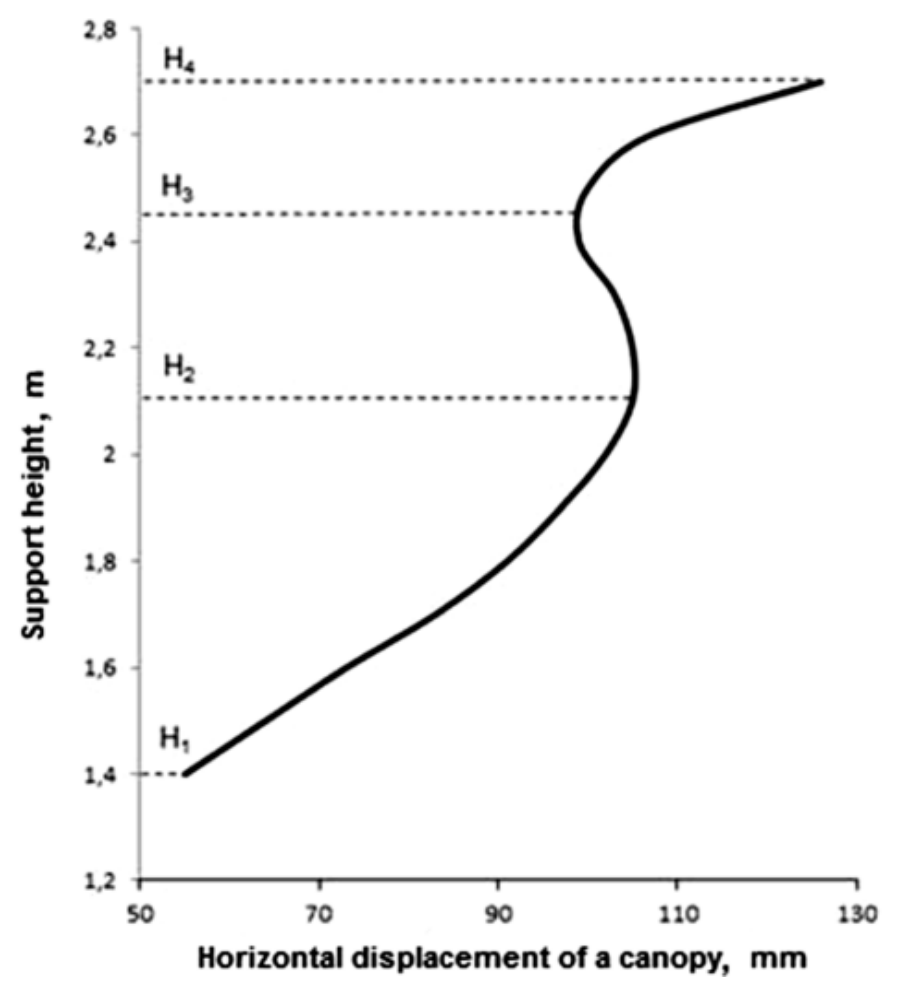

Fig. 11. Example of the lemniscate curve

Significantly better distribution of pressure on the floor is reported, when the horizontal component of roof support's external load - in most cases it can be identified as the force of friction between canopy and roof - has, during the roof convergence, a sense towards the gob. Forcing the sense towards the gob requires monotonic lemniscate curve within the entire operational heights of the roof support operation.

\section{Summary}

Results of theoretical analyses made with use of FEM method clearly indicate for the necessity of considering the uneven distribution of pressure on the floor in planes both perpendicular and parallel to the longwall face.

Considering the problem of cooperation of powered roof support with the floor of low load-bearing capacity as well as design of roof support, the following aspects should be taken into account:

- design of roof support should force (during roof convergence) the sense of friction force towards the gob - monotonic lemniscate curve within the entire heights range of roof support operation and should be of inclination that ensures movement of the canopy towards longwall face during roof convergence, 
- initial and operational load-bearing capacity of the roof support should be settled on the lowest possible level, however ensuring correct cooperation of the roof support with the longwall roof; too low load-bearing capacity can result in high roof convergence just after roof support setting to load as well as in excessive break of rocks in a direct roof and it can deteriorate proper cooperation of roof support with rock mass,

- the base should be designed in such a way to ensure the possibly greatest surface contact with the floor e.g. by maximal elongation of the base towards the longwall face,

- as two-row roof supports have better distribution of pressure on the floor comparing to one-row roof supports (Markowicz, 1997), in the case of soft floors, the possibility of using two-row roof supports with lemniscate guidance of the canopy should be considered instead of using one-row roof support. The hydraulic system of two-row roof support should allow setting different initial load-bearing capacities for each row of powered roof supports.

\section{References}

Bukowiecki B., Gałuszka A., Szweda S., 2012. Optymalizacja cech geometrycznych łańcucha kinematycznego mechanizmu na przykładzie sekcji obudowy zmechanizowanej. Przegląd elektrotechniczny, nr 3a, s. 131-138.

Bukowiecki B., Szweda S., 2010. Analiza ograniczeń naktadanych na cechy geometryczne nowoczesnych sekcji obudowy zmechanizowanej. [W:] Polski Kongres Górniczy 2010. Materiały Konferencyjne Kongresu Górnictwa Podziemnego, Gliwice, 9-10 September 2010. T. 2: Górnictwo podziemne. Gliwice, Katedra Elektryfikacji i Automatyzacji Górnictwa Politechniki Śląskiej, s. 215-224.

Gricajuk B.I., 1979. O wzaimodejjstvii dvustoechnojj ograditel'no poddierzhivajushhejj mekhanizirovannoj krepi z pochvojj, Ugol, nr 1, s. 48-52.

Jaszczuk M., Markowicz J., Szweda S., Kaczmarczyk A., 2008. Analiza rozkładu nacisku spagu na spagnice i stropu na stropnice metoda Jacksona wraz z programem komputerowym. Praca niepublikowana, s. 2-4.

Łaczek S., 2011. Modelowanie i analiza konstrukcji w systemie MES Ansys v. 11. Wydawnictwo Politechniki Krakowskiej, Kraków 2011.

Markowicz J., 1997. Wyznaczanie nacisków spagnicy obudowy zmechanizowanej na spagg wyrobiska. Przegląd Górniczy, 2/97, s. 1-7.

Markowicz J., 2010. Analysis of impact of welded joint damages and corrosion in powered roof support components on their operational safety. Arch. Min. Sci. 55, 4, 799-826.

Markowicz J., 2000. Modelowanie współpracy spagnicy obudowy zmechanizowanej ze spągiem. V Krajowa Konferencja Użytkowników Oprogramowania MSC Warszawa - Rynia Materiały konferencyjne, s. 139-145.

Markowicz J., 1985. Wyznaczanie obcią̇enia obudowy zmechanizowanej poprzez pomiar sit w wybranych elementach sekcji. Praca doktorska, Gliwice, 1985, s. 49-52.

Płonka M., Rajwa S., 2009. Podporność i rozkłady sit w węzłach sekcji obudowy zmechanizowanej. Wiadomości Górnicze, nr 10, s. 611-617.

Ptak J., Ślusarz R., 2010. Porównanie nacisków obudowy Glinik 14/35-Poz na spag obliczonych metodą analityczna i metoda Jacksona. Mechanizacja i Automatyzacja Górnictwa, nr 5, s. 16-21.

Szweda S., 1987. A field of application of roof supports with respect to a criterion of a floor-bottom sprag co-operation. Zborník referatov. BVTK Bánská mechanizácia. ČSVTS Košice, s. 155-166.

GEOSOFT, 2013. Geomechanics and Control of Soft Mine Floors and Sides. Report from the project realized within Research Fund for Coal and Steel (RFCS) No. RFCR-CT-2010-00001, years of realization: 2010-2013. 